\section{Identification and detection of a void under highway cement concrete pavement slabs based on finite element analysis}

\author{
Tao Zhang; Yongming Ren \\ Yellow River Conservancy Technical Institute, Kaifeng, Henan 475004, China
}

The Mining-Geology-Petroleum Engineering Bulletin UDC: 625

DOI: $10.17794 /$ rgn.2019.3.5

Preliminary communication

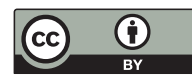

\begin{abstract}
For a city, the construction of a road is related to the development of economy, and the construction of a road includes maintenance of the road. Cement roads have been popularized in road construction due to their low construction cost and high strength, but at the same time, road problems have arisen. In order to solve and prevent the problem of voids under highway cement concrete pavement slabs, the acoustic vibration method was used for the detection of voids under highway cement concrete pavement slabs. This method was briefly introduced and analysed with finite element analysis. Then, excitation equipment and ABAQUS software were used to perform instance analysis on the section from Ko8-ooo to Ko9-0oo of G325 National Road. The results showed that there were three situations, including a mild void, normal void and serious void. The degree of abrupt change of the peak amplitude of the acoustic vibration characteristic curve increased with an increase in the severity of the void under the highway cement concrete pavement slabs. The void area was obtained through calculation of the sound pressure characteristic curve data based on the finite element model, with an error between $\mathbf{1 7 . 0}$ and $21.9 \%$. However, in road maintenance projects, this error is acceptable. In summary, the acoustic vibration method based on finite element analysis can effectively detect the position of a void under highway cement concrete pavement slabs and estimate the area.
\end{abstract}

\title{
Keywords:
}

finite element analysis, void under slabs, cement road, acoustic vibration method.

\section{Introduction}

Highways made of cement have advantages such as high strength, high bearing capacity and high stability. Therefore, cement is often used in the construction of highways (Liu et al., 2015). However, if cement concrete roads are not maintained for a long time, structural damage will occur, resulting in road disasters, thus affecting residents' travel and economic development (Wei et al., 2017). The most common road hazard is a void under highway cement concrete pavement slabs, which is a void between the layers of the road. The causes of a void under highway cement concrete pavement slabs (Liu et al., 2014) are divided into external and internal factors. The internal factors include topographical factors and defects of the cement road. The former is an inevitable internal cause. The terrain of China is stepped down from west to east. At the same time, there are many plateaus and mountains in the west. In the eastern plains, the geological conditions are very different. In the construction of highways, it is inevitable that mountain cracks will occur, resulting in uneven settlement of the roadbed (Bieliatynskyi et al., 2016). Internal factors

Corresponding author: Tao Zhang

tzhang_zt@126.com include situations where the basement stiffness of the cement road is less than the surface stiffness and under pressure, this causes different deformations and voids. The external factors are mostly controllable factors, such as rain erosion, water penetration corrosion causing voiding, which can be avoided by strengthening the construction of the drainage system, as well as road seams which are unfilled in time, resulting in increased rainwater infiltration, low subgrade density and uneven settlement (Zhou et al., 2017). Voids under highway cement concrete pavement slabs of a cement road will cause serious road disasters. Therefore, accurate detection technology is needed to identify defects and prevent voids under highway cement concrete pavement slabs.

Amhaz et al. (2016) proposed an automatic crack detection algorithm based on a two-dimensional road image, which was a natural method considering the luminosity and geometric features of a road surface image. Compared with the existing five methods, the proposed algorithm provided very powerful and accurate results in a completely unsupervised manner in all situations. Seraj et al. (2016) used smart phones, including global position system (GPS) and inertial sensors with accelerometers and gyroscopes for road surface monitoring. This method used time domain, frequency domain and wavelet transform to perform a wavelet decomposition 
analysis on inertial sensor signals, and then used a support vectors machine to detect and classify the abnormal situations. The experimental results showed that this method had a 90\% accuracy rate. Radopoulou et al. (2015) proposed a method for detecting road plaques using video data acquired by a parking lot camera. This method, which was based on the visual characteristics of the plaque, avoided high costs by using the data collected from a parking lot camera. The results showed that the method had an accuracy of $84 \%$ and a recall rate of $96 \%$. This study briefly introduced the acoustic vibration method for the detection of voids in roads and conducted a simple finite element theory analysis. Then, the excitation device and ABAQUS software were used to carry out an example analysis on the section from K08000 to K09-000 of the G30 national road.

\section{Thin plate acoustic vibration theory based on finite element analysis}

In order to facilitate the calculation, the thin plate used in the theoretical analysis in this study is ideal for the isotropic and equal thickness, and the middle surface of the thin plate is represented by a plane rectangular coordinate system. The expression of the strain, stress and displacement of the thin plate is:

$$
\left\{\begin{array}{l}
{[\varepsilon]=\left[-\frac{\partial^{2} w}{\partial x^{2}},-\frac{\partial^{2} w}{\partial y^{2}},-2 \frac{\partial^{2} w}{\partial x \partial y}\right]^{T}} \\
\{M\}=\left[M_{x}, M_{y}, M_{x y}\right]^{T} \\
{[U]=[u, v, w]^{T}}
\end{array}\right.
$$

Where:

[E] - the strain set of different points of the thin plate,

$\{M\} \quad-$ the stress set of different points of the thin plate,

$[U]-$ the displacement set of each point of the thin plate,

$w \quad-$ the deflection of the thin plate,

$x$ and $y$-the coordinates of each point of the thin plate,

$u \quad-$ the displacement of each point of the thin plate in the axial direction $x$,

$v \quad-$ the displacement of the point in the direction of the axis $y$.

Equation (1) can be expressed in the form of a matrix:

$$
\{\mathrm{M}\}=[\mathrm{D}][\varepsilon]
$$

Where:

$[D]$ - elastic matrix of each point of the thin plate.

According to the principle of minimum potential energy, the displacement of each point when the thin plate has minimum potential energy is obtained, and the free vibration equation of the thin plate is deduced:

$$
\left\{\begin{array}{l}
\nabla^{2}\left(\nabla^{2} \mathrm{w}\right)=-\frac{\rho \mathrm{h}}{\mathrm{gD}} \frac{\partial^{2} \mathrm{w}}{\partial \mathrm{t}^{2}} \\
\nabla^{2}=\frac{\partial^{2}}{\partial \mathrm{x}^{2}}+\frac{\partial^{2}}{\partial \mathrm{y}^{2}}
\end{array}\right.
$$

Where:

$\nabla^{2}$ - the Laplacian operator,

$\rho$ - the density of the thin plate,

$h$ - the thickness of the thin plate,

$g$ - the constant of the surface gravity,

$t$ - the vibration time,

$D$ - bending stiffness of the thin plate

$\partial$ - partial differential.

Due to limited space and the practical application of the plate vibration theory in this study, only the foursided simply supported thin plates were analyzed. The characteristic function of a four-sided simply supported thin plate can be expressed by the following formula:

$$
\varpi=\sum_{m=1}^{\infty} \sum_{n=1}^{\infty} C_{m n} \sin \frac{m \pi x}{a} \sin \frac{n \pi y}{b}
$$

Where:

ळ- the natural frequency of the thin plate,

$m$ and $n-$ the number of resonant modes,

$C_{m n} \quad$ - the unknown coefficient,

$a^{m n} \quad-$ the length and width of the thin plate,

$b \quad-$ the width of the thin plate.

Then the finite element analysis method (Niyogi et al., 2015) is used to solve Equation (4) under the free boundary condition. The steps are as follows:

The thin plate is divided as mesh, and the dividing unit (Yadav et al., 2015) may be a triangle or a rectangle. The number of the dividing units is adjusted according to actual needs. Usually, the division of the part of the stress concentration is relatively dense because this part should be accurate. The dividing unit is analyzed alone. The displacement of the points in the segmentation unit represents the node displacement. In the rectangular element, the equation can be obtained according to the displacement mode and the node displacement equation (Azam et al., 2015):

$$
[\mathrm{w}]=[\mathrm{N}][\mu]^{\mathrm{e}}
$$

Where:

$[w]$ - the set of node displacements in the Z-axis direction,

$[N]$ - a function matrix representing the shape of the joint of the nodes,

$[\mu]^{\mathrm{e}}-$ a displacement array of the split unit nodes.

The strain and stress of the segmentation unit can be deduced from Equation (1), (2) and (5) as: 


$$
\left\{\begin{array}{l}
{[\varepsilon]=[\mathrm{B}][\mu]^{\mathrm{e}}} \\
\{\mathrm{M}\}=[\mathrm{D}][\mathrm{B}][\mu]^{\mathrm{e}}
\end{array}\right.
$$

Where:

$[B]$ - the deformation matrix of the segmentation unit.

Then based on the principle of minimum potential energy, we can obtain:

$$
\left\{\begin{array}{l}
\Pi^{\mathrm{e}}=\mathrm{U}^{\mathrm{e}}-\mathrm{W}^{\mathrm{e}} \\
{[\mathrm{F}]^{\mathrm{e}}=[\mathrm{K}]^{\mathrm{e}}[\mu]^{\mathrm{e}}}
\end{array}\right.
$$

Where:

$\Pi^{\mathrm{e}}$ - the potential energy of the segmentation unit,

$U^{e}$ - the displacement of the segmentation unit,

$W^{E}$ - the mode shape function of the segmentation unit,

$[F]^{e}$ - the force array of the segmentation unit nodes,

$[K]^{e}$ - the stiffness matrix of the segmentation unit.

After the basic vibration equation of the segmentation unit is obtained, the motion equation of the thin plate can be obtained according to the relationship between the segmentation units (Sugimoto et al., 2017):

$$
\left([\mathrm{K}]-\varpi^{2}[\mathrm{M}]\right)\left[\mu_{0}\right]=0
$$

Where:

$[K]$ - the overall stiffness matrix,

$[M]$ - the overall mass matrix,

$\left[\mu_{0}\right]$ - the overall node displacement matrix.

The subspace iteration method can then be applied to obtain vibration characteristics of the thin plate and the natural vibration frequency $\varpi$.

The acoustic vibration method used in this study is based on sound pressure. Therefore, it is necessary to convert the natural vibration frequency and sound pressure. The steps are as follows:

According to the vibration mode function and natural frequency of the plate vibration theory, the mode matrix is constructed, and the mode velocity matrix, the surface normal velocity matrix and the sound pressure matrix can be obtained (Veiga et al., 2017) as:

$$
\left\{\begin{array}{l}
{[\mathrm{Q}]=\mathrm{i} \varpi[\Phi]=\left\{\left\{\mathrm{Q}_{1}\right\}\left\{\mathrm{Q}_{2}\right\} \cdots\left\{\mathrm{Q}_{\mathrm{n}}\right\}\right\}} \\
{[\mathrm{B}]=[\mathrm{G}]^{\mathrm{T}} \mathrm{i} \Phi[\Phi]=\left\{\left\{\mathrm{B}_{1}\right\}\left\{\mathrm{B}_{2}\right\} \cdots\left\{\mathrm{B}_{\mathrm{n}}\right\}\right\}} \\
{[\mathrm{H}]=[\mathrm{E}]^{-1}[\mathrm{D}][\mathrm{G}]^{\mathrm{T}} \mathrm{i} \varpi[\Phi]=\left\{\left\{\mathrm{H}_{1}\right\}\left\{\mathrm{H}_{2}\right\} \cdots\left\{\mathrm{H}_{\mathrm{n}}\right\}\right\}}
\end{array}\right.
$$

Where:

$\begin{array}{ll}{[Q]} & - \text { the vibration velocity matrix, } \\ {[B]} & - \text { the surface normal velocity matrix, } \\ {[H]} & \text { - the sound pressure matrix, } \\ \left\{\mathrm{Q}_{\mathrm{n}}\right\} & \text { - the } \mathrm{n}^{\mathrm{th}} \text { order mode velocity vector, } \\ \left\{\mathrm{B}_{\mathrm{n}}\right\} & \text { - the surface normal velocity vector } \\ \left\{\mathrm{H}_{\mathrm{n}}\right\} & \text { - the sound pressure vector } \\ {[\Phi]} & \text { - a mode matrix, }\end{array}$

$[G]^{T} \quad-$ the transformation matrix of unit road plate node between the velocity vector and the normal velocity vector

$[E]^{-1}$ and $[D]$ - the transformation matrix between the surface normal velocity matrix and the sound pressure matrix.

The following can be obtained by combining with $\{\mathrm{x}\}$ and the mode matrix $[\Phi]$ in Equation (9) (Li et al., 2017):

$$
\left\{\begin{array}{l}
\{\mathrm{x}\}=[\Phi]\{\mathrm{q}\} \\
\{\mathrm{v}\}=[\mathrm{Q}]\{\mathrm{q}\} \\
\left\{\mathrm{v}_{\mathrm{T}}\right\}=[\mathrm{B}]\{\mathrm{q}\} \\
\{\mathrm{p}\}=[\mathrm{H}]\{\mathrm{q}\}
\end{array}\right.
$$

where:

$[\Phi]$ - a linear transformation matrix between the node displacement and the node coordinate $\{\mathrm{q}\}$,

$\{v\}-$ the node velocity vector,

$\left\{\mathrm{v}_{\mathrm{T}}\right\}$ - the node normal velocity vector,

$\{\mathrm{p}\}$ - the surface sound pressure.

\section{Instance analysis}

To verify the role of a finite element analysis in the detection of a void under highway cement concrete pavement slabs, the section from K08-000 to K09-000 in the G30 national highway in the Jiangsu province, China was selected for instance analysis.

\subsection{Road profile}

The road section was a first-grade cement road with two ways and four lanes. The overall condition was good, but the joint between some of the panels had serious damage. At the same time, after investigation, when a vehicle with a heavy load passed the section, the driver could obviously hear the echo of the plate. The road structure of this section is shown in Figure 1. From top to bottom, it was a panel layer $(23 \mathrm{~cm})$, a semi-rigid base layer $(20 \mathrm{~cm})$ and a roadbed. The panel layer was made of cement concrete, and the semi-rigid base layer was made of cement stabilized macadam.

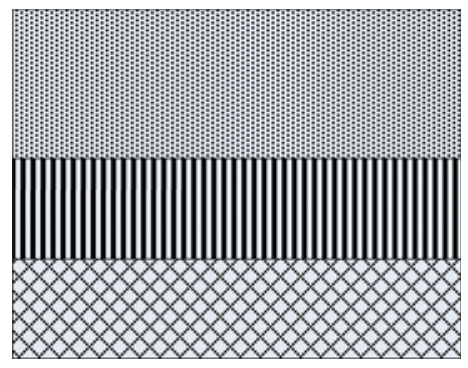

Figure 1: Structural layer of the experimental highway 


\subsection{Model establishment}

This study used the professional finite element analysis software, ABAQUS software (Mcgovern et al., 2016), to build a model of the experimental section. The software had an excellent structural analysis and nonlinear computing ability, and the acoustic-solid coupling model algorithm of the software is beneficial to the analysis of the acoustic signal of the experimental road.

As shown in Figure 2, in the finite element calculation model of the experimental pavement, the blue part of the bottom was the roadbed, the elastic modulus was set as $45 \mathrm{MPa}$, and the thickness was $6 \mathrm{~m}$. To ensure the accuracy of calculation, the plain view size of the unit roadbed was $5 \times 4 \mathrm{~m}^{2}$. The red part was a semi-rigid base layer with an elastic modulus of $2000 \mathrm{MPa}$, and the thickness of the red part was $0.2 \mathrm{~m}$. The unit semi-rigid base layer had a plain view size of $2.5 \times 2 \mathrm{~m}^{2}$. The yellow part was the panel layer, the elastic modulus was set as $31000 \mathrm{MPa}$, the thickness of the yellow part was $0.25 \mathrm{~m}$, and the plain view size of unit panel layer was $2.5 \times 2 \mathrm{~m}^{2}$.

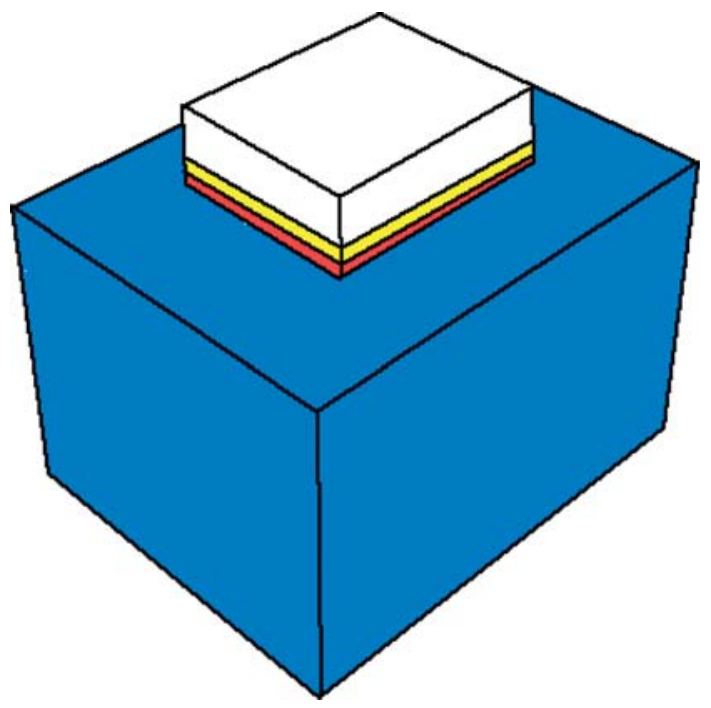

Figure 2: Finite element calculation model of the experimental road
The white part was the air layer with no elastic modulus, which was set as the acoustic unit and was constraintcoupled with a panel layer with a "Tie" which is a connection definition command and represents the connection of two adjacent units. The thickness of the white part was $1 \mathrm{~m}$, and the plain view size of the unit air layer was $2.5 \times 2 \mathrm{~m}^{2}$.

\subsection{Detection method}

The traction excitation device was used to apply periodic excitation to the experimental road surface, where the excitation device was a trailer wagon that can be towed. The trailer wagon had a chassis which could record data, a heavy hammer which was used for applying the excitation vibration, which was connected with the axle through the traction belt and the lever to realize harmonic excitation, had a weight of $5 \mathrm{~kg}$, and had a fall distance of $20 \mathrm{~cm}$, and a microphone which was used for collecting sound vibrations. When the excitation device periodically struck the road surface, the road surface was forced to vibrate, and the generated sound was collected by the microphone. After being amplified and filtered, it was transmitted to the computer, a sound pressure curve was drawn, and the sound pressure curve data was substituted into the model in ABAQUS software to identify the void size.

\subsection{Judgement index}

In this study, a void larger than $0.4 \mathrm{~m}$ was considered as severe and a void smaller than $0.4 \mathrm{~m}$ was considered as normal. According to the simulation results of the finite element calculation model in ABAQUS software, the abrupt change indicator of the sound pressure which was used to judge the void was $0.026 \mathrm{~Pa}, 0.011 \mathrm{~Pa}$ and $0.006 \mathrm{~Pa}$. The area was suspected to be a void if its abrupt change of peak of the sound pressure curve of the experimental road surface was between $0.006 \mathrm{~Pa}$ and $0.011 \mathrm{~Pa}$. It was a normal void if its abrupt change was between $0.011 \mathrm{~Pa}$ and $0.026 \mathrm{~Pa}$. It was a severe void if its abrupt change was above $0.026 \mathrm{~Pa}$. It was no void if its

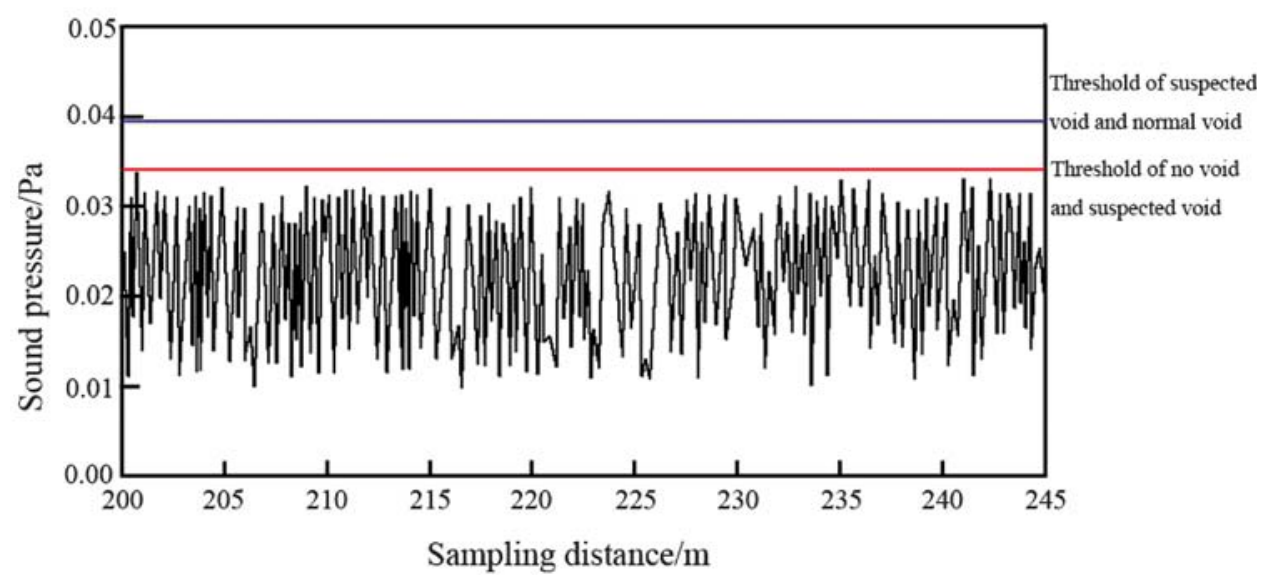

Figure 3: Sound pressure characteristic curve of the section from Ko8-20o to Ko8-245 
abrupt change was below $0.006 \mathrm{~Pa}$. Combined with the detected sound pressure data, the critical range could be obtained: a sound pressure of less than $0.035 \mathrm{~Pa}$ for no void, 0.035 0.039 $\mathrm{Pa}$ for a suspected void, 0.039 0.054 $\mathrm{Pa}$ for a normal void, and above $0.054 \mathrm{~Pa}$ for a severe void.

\subsection{Detection results}

As shown in Figure 3, the overall difference of the peak amplitude in the sound pressure characteristic curve of the section from K08-200 to K08-245 was not large, and only the difference between the peak changes of the section from K08-215 to K08-235 in the section was relatively large. However, the peak change was still less than $0.019 \mathrm{~Pa}$. According to the relative standard of the void judgement obtained from the simulation, it was preliminarily judged that there was no void in the section.

As shown in Figure 4, it can be clearly seen, that as a whole, the peak amplitude of the curve had a difference and the fluctuation was obvious in the sound pressure characteristic curve of the section from K08-270 to K08350 . The peak changes of the section from K08-270 to K08-290 and the section from K08-320 to K08-350 were obviously larger than the peak changes in Figure 3, but not more than $0.041 \mathrm{~Pa}$. According to the relative standard of the void detection obtained from the simulation, the preliminary judgment of the section of the road

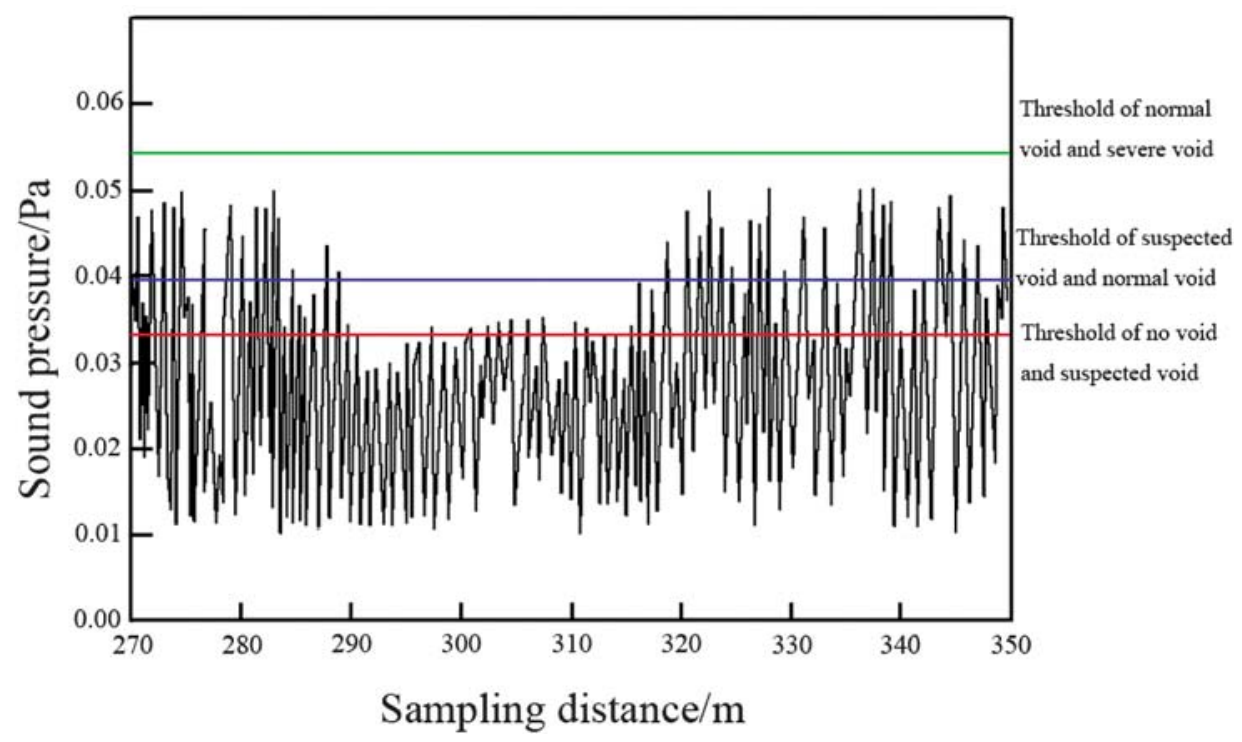

Figure 4: Sound pressure characteristic curve of the section from Ko8-270 to Ko8-350

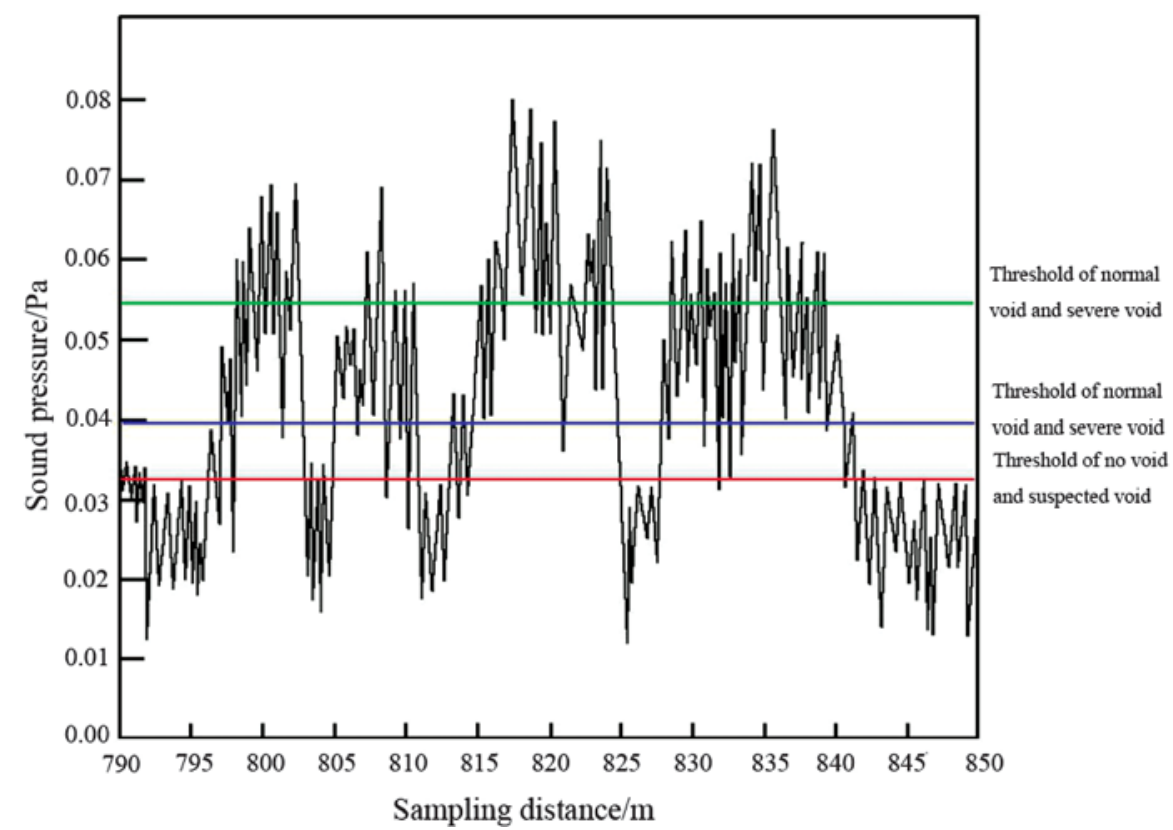

Figure 5: Sound pressure characteristic curve of the section from Ko8-79o to Ko8-850 
was a normal void. The peak changes of the section from K08-290 to K08-320 was relatively larger than that of Figure 3, but it was obviously smaller in this section. Thus, the section from K08-290 to K08-320 was suspected to have a mild void.

As shown in Figure 5, the peak amplitude changes in the sound pressure characteristic curve of the section from K08-790 to K08-850 were very obvious, and the abrupt change was much larger than the mutation degree in Figure 4, especially the section from K08-795 to K08-843. The abrupt change was significantly greater than $0.041 \mathrm{~Pa}$, which was considered to be a serious void in this section of the road. The difference of the peak amplitude of the road after the section of K08-843 was basically negligible, and it was considered that there was no void.

As shown in Table 1, by substituting the sound pressure characteristic curve data of the three detection sections into the model of ABAQUS software, the void area of the section from K08-200 to K08-245 was $0.117 \times$ $10^{-2} \mathrm{~m}^{2}$ after calculation, the section from $\mathrm{K} 08-270$ to K08-350 was $22.011 \times 10^{-2} \mathrm{~m}^{2}$, and the section from K08790 to $\mathrm{K} 08-850$ was $48.161 \times 10^{-2} \mathrm{~m}^{2}$. After that, the three detection sections were maintained according to the detection result, and the actual void areas were measured, which were respectively $0.100 \times 10^{-2} \mathrm{~m}^{2}, 18.512 \times 10^{-2} \mathrm{~m}^{2}$ and $39.502 \times 10^{-2} \mathrm{~m}^{2}$. It could be seen that there was a difference between the void area obtained by the acoustic vibration method and the actual void area. The void area detected by the acoustic vibration method was too large, and the errors were respectively $17.0 \%, 18.9 \%$, and $21.9 \%$. The reason for the error might be mainly because the model established by ABAQUS software was different from the actual pavement structure, and the actual road surface condition could not be completely simulated. In addition, the interference of the detecting instrument was also a cause, except for the hammering of the heavy hammer in the process of pulling the excitation device. In addition to the sound, there would be other noise, and the filtering device could not completely eliminate the noise. In short, although the acoustic vibration method had errors in the calculation of the void

Table 1: Judgment and error of the size of the void by sound vibration method

\begin{tabular}{|l|l|l|l|}
\hline Section & $\begin{array}{l}\text { From } \\
\text { K08-200 to } \\
\text { K08-245 }\end{array}$ & $\begin{array}{l}\text { From } \\
\text { K08-270 to } \\
\text { K08-350 }\end{array}$ & $\begin{array}{l}\text { From } \\
\text { K08-790 to } \\
\text { K08-850 }\end{array}$ \\
\hline $\begin{array}{l}\text { The area of the void } \\
\text { obtained by acoustic } \\
\text { vibration method/ } \\
\times 10^{-2} \mathrm{~m}^{2}\end{array}$ & 0.117 & 22.011 & 48.161 \\
\hline $\begin{array}{l}\text { The area of the void } \\
\text { obtained by actual } \\
\text { maintenance/ } \\
\times 10^{-2} \mathrm{~m}^{2}\end{array}$ & 0.100 & 18.512 & 39.502 \\
\hline Error/\% & 17.0 & 18.9 & 21.9 \\
\hline
\end{tabular}

area, it could effectively identify the void under highway cement concrete pavement slabs in highway inspection and provide a reference for highway maintenance.

\section{Conclusion}

This study briefly introduced the acoustic vibration method for the detection of the bottom of the road, and conducted a simple finite element theory analysis. Then, the excitation device and ABAQUS software were used to carry out an example analysis of the section from K08-000 to K09-000 of the G325 national highway. The overall difference of the peak amplitude in the sound pressure characteristic curve of the section from K08200 to K08-245 was not large, the abrupt change was less than $0.006 \mathrm{~Pa}$, the calculated void area was $0.117 \times 10^{-2} \mathrm{~m}^{2}$, the actual void area was $0.100 \times 10^{-2} \mathrm{~m}^{2}$, and the error was $17.0 \%$, which was a mild void. The overall difference of the peak amplitude in the sound pressure characteristic curve of the section from K08270 to K08-350 was relatively more obvious, the abrupt change was between $0.006 \mathrm{~Pa}$ and $0.026 \mathrm{~Pa}$, the calculated void was $22.011 \times 10^{-2} \mathrm{~m}^{2}$, the actual void was $18.512 \times 10^{-2} \mathrm{~m}^{2}$, and the error was $18.9 \%$, which was a normal void. The overall difference of the peak amplitude in the sound pressure characteristic curve of the section from $\mathrm{K} 08 \times 10^{-2} \mathrm{~m}^{2}-790$ to $\mathrm{K} 08-850$ was very obvious, the abrupt change was over $0.026 \mathrm{~Pa}$, the calculated void area was 48.161, the actual void area was $39.502 \times 10^{-2} \mathrm{~m}^{2}$, and the error was $21.9 \%$, which was a severe void.

\section{References}

Amhaz, R., Chambon, S., Idier, J., and Baltazart V. (2016): Automatic crack detection on two-dimensional pavement images: an algorithm based on minimal path selection. IEEE Transactions on Intelligent Transportation Systems, $17,10,2718-2729$.

Azam, M. S., Ranjan, V. and Kumar, B. (2015): Finite element modelling and analysis of free vibration of a square plate with side crack. Differential Equations \& Dynamical Systems, (1), 1-13.

Bieliatynskyi, A., Krayushkina, E. and Skrypchenko, A. (2016). Modern technologies and materials for cement concrete pavement's repair. Procedia Engineering, 134, 3, 344-347.

Li, S.L., Wu, G.M. and Shi, H.S. (2017): Acoustic emission characteristics of semi-rigid bases with three moisture conditions during bending tests. Road Materials \& Pavement Design, 2017, 2, 1-12.

Liu, Z.G., Li, J.N. and Cao, G.B. (2014): The treatment technology of void beneath cement concrete pavement bottom in cold area. Advanced Materials Research, 1049-1050, 339-341.

Liu, Z.G., Xu, F.M. and Cao, G.B. (2015): Study on cement concrete pavement treatment methods of common dama- 
ge diseases. Applied Mechanics \& Materials, 716-717, 307-309.

Mcgovern, M.E., Buttlar, W.G. and Reis, H. (2016): Field assessment of oxidative aging in asphalt concrete pavements with unknown acoustic properties. Construction \& Building Materials, 116, 159-168.

Niyogi, A.G., Laha, M.K. and Sinha, P.K. (2015): Finite element vibration analysis of laminated composite folded plate structures. Shock \& Vibration, 6, (5-6), 273-283.

Radopoulou, S.C. and Brilakis, I. (2015): Patch detection for pavement assessment. Automation in Construction, 53, 95-104.

Seraj, F., Zwaag, B.J.V.D., Dilo, A., Luarasi, T. and Havinga, P. (2016): RoADS: a road pavement monitoring system for anomaly detection using smart phones. Big Data Analytics in the Social \& Ubiquitous Context.

Sugimoto, K., Sugimoto, T., Utagawa, N. and Katakura, K. (2017): The defect detection algorithm that combined spectrum entropy with vibrational energy ratio for acoustic inspection method. Acoustical Society of America Journal, 141, 5, 3831-3831.

Veiga, L.B.D., Mora, D., Rivera, G. and Rodriguez, R. (2017): A virtual element method for the acoustic vibration problem. Numerische Mathematik, 136, 3, 1-39.

Wei, Y., Gao, X., Wang, F. and Zhong, Y. (2017): Nonlinear strain distribution in a field-instrumented concrete pavement slab in response to environmental effects. Road Materials and Pavement Design, 1-14.

Yadav, D., Sharma, A. and Shivhare, V. (2015): Free vibration analysis of isotropic plate with stiffeners using finite element method. Engineering Solid Mechanics, 3, (3), 167-176.

Zhou, S., Liang, J. and Shen, A. (2017): A strength damage and fatigue life prediction model of pavement cement concrete under loading low-temperature drying conditions. Journal of Highway \& Transportation Research \& Development, 11, 2, 9-13.

\section{SAŽETAK}

\section{Prepoznavanje i opažanje šupljina ispod ploča kolničkoga cementnom ojačanoga betona na prometnicama uporabom analize konačnih elemenata}

Izgradnja prometnica u gradu povezana je s razvojem ekonomije, a uključuje i njihovo održavanje. Betonske prometnice, ojačane cementom, bile su često u uporabi zbog njihova maloga troška i velike trajnosti. Međutim postoje i problemi takvih konstrukcija. U cilju smanjivanja problema izazvanih šupljinama ispod takvih betonskih ploča ovdje je prikazana uporaba metode zvučnih vibracija. Njome opažene šupljine analizirane su metodom konačnih elemenata. Odgovarajućom opremom i programskim paketom ABAQUS analizirana je dionica nacionalne ceste od sekcije Kog-ooo do sekcije Ko9-ooo. Rezultati su pokazali tri slučaja - one s malim, uobičajenim i velikim šupljinama. Stupanj nagle promjene vršne amplitude zvučne vibracije povećavao se što su šupljine u podlozi ceste bile veće. Karakteristične krivulje odziva zvučnoga vala izračunane su metodom konačnih elemenata, uz pogrješku procjene 17 - 21,9 \%. To je prihvatljiv iznos kod projekata održavanja prometnica. Time je metoda zvučnih vibracija te primjena analize konačnih elemenata pokazala svoju uporabivost kod određivanja smještaja šupljina u podini prometnica izgrađenih od cementom ojačanog betona.

\section{Ključne riječi:}

analiza konačnih elemenata, šupljine podine, cementne prometnice, metoda zvučnih vibracija

\section{Authors contribution}

Tao Zhang (master's degree) put forward detection of a void under highway cement concrete pavement slabs using finite element analysis method and acoustic method and performed a field investigation of the Ko8-ooo Ko9-ooo section of G30. Yongming Ren (master' degree) performed an acoustic vibration detection of Ko8-ooo Ko9-ooo section of G30, carried out finite element modelling according to the investigation data, and calculated the void under highway cement concrete pavement slabs according to the acoustic vibration data. 